www.jmscr.igmpublication.org Impact Factor 5.244

Index Copernicus Value: 83.27 ISSN (e)-2347-176x ISSN (p) 2455-0450 crossref DOI:_https://dx.doi.org/10.18535/jmscr/v4i12.102

\title{
Assessment, Monitoring and Reporting of Adverse Drug Reactions Due to Polypharmacy
}

Authors

\section{Dr M Sureswara Reddy ${ }^{1}$, K Thirumala Naik ${ }^{2}$, L Kavya $^{3}$, J Harini ${ }^{4}$, K Sirisha ${ }^{5}$,} A Shiva ${ }^{6}$, M Venkata Subbaiah $^{7}$

${ }^{1}$ Associate professor, Department of General Medicine, RIMS, Kadapa, India

${ }^{2}$ Pharm-D Intern, Dept of Pharmacy Practice, Rajiv Gandhi Institute of Medical Sciences, Kadapa, India

${ }^{3,4,5,6}$ Pharm-D Interns, Dept of Pharmacy Practice, Rajiv Gandhi Institute of Medical Sciences, Kadapa,India

${ }^{7}$ Assistant Professor, Department of Pharmacy practice, PRRMCP, Kadapa, India

*Corresponding Author

K Thirumala Naik

Pharm- D Intern, Department of Pharmacy Practice, RIMS, PRRMCP, Kadapa, India - 516001

Email:dr.ktnaik@gmail.com, Contact No.+919989723490

\section{ABSTRACT}

Poly-pharmacy significantly increases the likelihood of adverse reactions to drugs, risk of hospitalization and medication errors related to drugs. It depends on the number of drugs, the disease and patient related factors. Poly-pharmacy is a major risk factor for severe adverse drug reactions (ADR'S) and is associated with increased risk of mortality. The main aim of this study was to assessment and monitoring of polypharmacy leading to adverse drug reaction. A Prospective observational study was carried out in Rajiv Gandhi institute of medical sciences (RIMS), a 750 bedded tertiary care teaching hospital, Kadapa, for the period of 7 months in the all deportments of hospital. A total of 448 cases of polypharmacy were identified, among that males were 246 and females were 202. Out of 448 cases, 252 patients were major polypharmacy and 196 were minor polypharmacy. Among 114 ADRs, 22.80\% from MICU, 31.57\% from MMW, 27.19\% from FMW, 10.52\% from PSY and 7.89 from DVL, The identified ADRs were reported to physician and the causality assessment was done for 114 ADRs by using Naranjo's scale. According to Naranjo's scale 24 (60.28\%) ADRs were definitely, 52 (57.42\%) were probable, 38 (81.37\%) were possible. The role of pharmacists is important to continually educate but also to have access to complete patient records. So they could look at all of the medications that may be given to the patient for better patient care.

Keywords: ADR's, Poly pharmacy, Assessment, Monitoring and Outcomes.

\section{INTRODUCTION}

Poly-pharmacy significantly increases the likelihood of adverse reactions to drugs, risk of hospitalization and medication errors related to drugs. It depends on the number of drugs, the disease and patient related factors. Poly-pharmacy is a major risk factor for severe adverse drug reactions (ADR'S) and is associated with increased risk of mortality ${ }^{1}$. Poly-pharmacy carries negative connotations, including increased costs, poorer compliance and increased risk of side effects, drug interactions and adverse drug reactions $^{2}$. The World Health Organization (WHO) defines an adverse drug reaction (ADR) 
as "any response to a drug which is noxious and unintended, and which occurs at doses normally used in man for prophylaxis, diagnosis or therapy of a disease, or for the modification of physiological function". Traditionally ADR'S are classified into two categories- Type-A (Augmen-ted) and Type-B (Bizzare) reactions ${ }^{3}$. Poly-pharmacy medications are the most commonly used in clinical intervention and complications associated with their use constitute one of the most common causes of adverse drug reactions in heal is defined as the concomitant use of two or more drugs and or the administration of more medications than are clinically indicated, representing unnecessary drug use and it could enhance drug interactions and adverse drug reactions ${ }^{4}$. Adverse drug reactions are recognized hazards of drug therapy and it is an important cause of morbidity and mortality in both hospitalized and ambulatory patients ${ }^{5}$. ADR'S are the fourth leading cause of death ahead of pulmonary diseases, diabetes and acquired immune deficiency syndrome (AIDS) ${ }^{6}$. Multiple factors influence ADR susceptibility which includes multiple drug therapy, disease severity, age, drug interactions and number of drugs prescribed $^{7}$. ADR'S rank among the top 10 leading causes of mortality. So there is a need to study ADR'S seriously to create awareness about ADR'S among patients to motivate health care professionals in the hospital to report ADR'S to minimize the risk ${ }^{4}$.

\section{MATERIALS AND METHODS}

A Prospective observational study was carried out in Rajiv Gandhi institute of medical sciences (RIMS), a 750 bedded tertiary care teaching hospital. The main aim of this study was the assessment and monitoring of poly-pharmacy leading to adverse drug reaction. This study was including hospital in-patients who are treated for various diseases. Study was conducted between the periods of January 2016 to July 2106.

Inclusion criteria: Patients of age group between 20-70 years of both genders who admitted in hospital.
Exclusion criteria: Patients who are treated in out-patient departments, those who stayed in the hospital $<20$ hours were excluded.

The data was collected from the patient's case records, which included the medication history, for number of drugs prescribed and for number of possible drug interactions. Details of demographics, clinical manifestations, patient history and treatment regimen were collected. Causality assessment of reported ADR'S was carried out by using Naranjo's algorithm scale. In Naranjo's algorithm, the ADR'S are classified as Definitely, Probable, Possible and Unlikely.

\section{RESULTS}

During the study period total of 850 patients got admitted in hospital (FMW, MMW, PSY, MICU, and DVL), 250 patients did not meet the criteria as 50 patients stayed for less than 20 hours and 52 were either critically ill or on mechanically ventilated and few of them admitted for poisoning, then 448 cases of polypharmacy were identified.

Among 448 cases, males were 246 and females were 202. Out of 448 cases 252 patients were found to be with major polypharmacy and 196 were with minor polypharmacy. Out of 252 major polypharmacy patients, $34.12 \%$ of the patients were found in MICU followed by $55.55 \%$ in MMW, $14.28 \%$ in FMW, 10.31in PSY and 9.92\% in DVL. There are $51.75 \%$ ADRs were identified in males and $48.24 \%$ ADRs were identified in females. Among 114 ADRs, 22.80\% from MICU, $31.57 \%$ from MMW, 27.19\% from FMW, 10.52\% from PSY and 7.89 from DVL.

Categorization of polypharmacy was presented in table: 1, 2, and 3 based on age, gender and department. Our study showed that 252 patients receiving $\geq 6$ drugs, of these $11.79 \%$ of the patients received more than 10 drugs, $28.08 \%$ of the patients received $8-9$ drugs and $60.11 \%$ of the patients received 6-7 drugs. The medical diagnosis associated with polypharmacy was presented in table: 4. 
Table: 1 Categorization of polypharmacy based on age

\begin{tabular}{|l|c|c|c|c|c|c|c|}
\hline Age group & \multirow{2}{*}{ No. of patients } & \multirow{2}{*}{ ADRs } & \multirow{2}{*}{} & \multicolumn{4}{|c|}{ Polypharmacy } \\
\cline { 4 - 8 } & & & & Major & \% & minor & \% \\
\hline $20-40$ & 176 & 36 & 31.57 & 96 & 38.09 & 52 & 26.53 \\
$41-60$ & 109 & 59 & 51.75 & 156 & 61.90 & 96 & 48.97 \\
$61-70$ & 163 & 19 & 16.66 & 100 & 39.68 & 48 & 24.48 \\
\hline Total & $\mathbf{4 4 8}$ & $\mathbf{1 1 4}$ & $\mathbf{1 0 0}$ & $\mathbf{2 5 2}$ & $\mathbf{1 0 0}$ & $\mathbf{1 9 6}$ & $\mathbf{1 0 0}$ \\
\hline
\end{tabular}

Table: 2 Categorization of polypharmacy based on gender

\begin{tabular}{|l|c|c|c|c|c|c|c|}
\hline Gender & No. of patients & \multirow{2}{*}{ ADRs } & \multirow{2}{*}{} & \multicolumn{4}{|c|}{ Polypharmacy } \\
\cline { 4 - 7 } & & & & Major & \% & minor & \% \\
\hline Male & 246 & 59 & 51.75 & 156 & 61.90 & 105 & 53.57 \\
Female & 202 & 55 & 48.24 & 96 & 38.09 & 91 & 46.42 \\
\hline Total & $\mathbf{4 4 8}$ & $\mathbf{1 1 4}$ & $\mathbf{1 0 0}$ & $\mathbf{2 5 2}$ & $\mathbf{1 0 0}$ & $\mathbf{1 9 6}$ & $\mathbf{1 0 0}$ \\
\hline
\end{tabular}

Table: 3 Categorization of polypharmacy based on department

\begin{tabular}{|l|c|c|c|c|c|c|c|}
\hline Gender & No. of patients & \multirow{2}{*}{ ADRs } & \multirow{2}{*}{} & \multicolumn{4}{|c|}{ Polypharmacy } \\
\cline { 4 - 7 } & & & & Major & \% & minor & \% \\
\hline MICU & 105 & 26 & 22.80 & 86 & 34.12 & 42 & 21.42 \\
MMW & 86 & 36 & 31.57 & 140 & 55.55 & 76 & 38.77 \\
FMW & 122 & 31 & 27.19 & 75 & 14.28 & 30 & 15.30 \\
PSY & 70 & 12 & 10.52 & 26 & 10.31 & 20 & 10.20 \\
DVL & 65 & 9 & 7.89 & 25 & 9.92 & 18 & 9.18 \\
\hline Total & $\mathbf{4 4 8}$ & $\mathbf{1 1 4}$ & $\mathbf{1 0 0}$ & $\mathbf{2 5 2}$ & $\mathbf{1 0 0}$ & $\mathbf{1 9 6}$ & $\mathbf{1 0 0}$ \\
\hline
\end{tabular}

Table: 4 Medical diagnoses associated with polypharmacy

\begin{tabular}{|l|c|c|}
\hline Disorder & No. of patients & Percentage (\%) \\
\hline Respiratory & 72 & 16.07 \\
Cardiovascular & 102 & 22.76 \\
Renal & 78 & 17.41 \\
Endocrine & 48 & 10.71 \\
Hematological & 39 & 8.70 \\
Hepatic & 48 & 10.71 \\
Infection & 61 & 13.61 \\
\hline Total & $\mathbf{4 4 8}$ & $\mathbf{1 0 0}$ \\
\hline
\end{tabular}

Most commonly prescribed drugs were enalapril, followed by ceftriaxone, hydrocortisone, phenytoin and metformin. Out of the 114 ADRs, 105 were accepted by physician and 9 were suspected. Among them34 ADRs were Type-A (augmented), 84 ADRs were Type-B (bizzare). Of these 14 ADRs were identified in patients had minor polypharmacy and 100 ADRs in patients had major polypharmacy.

\section{ADRs ASSESSMENT}

The causality assessment was done for 114 ADRs by using Naranjo's scale. The detailed information was presented in table: 5. According to Naranjo's scale $24(60.28 \%)$ ADRs were definitely, 52 $(57.42 \%)$ were probable, $38(81.37 \%)$ were possible. 


\section{JMSCR Vol||04||Issue||12||Page 14926-14931||December}

Table: 5 Severity of ADRs based on polypharmacy

\begin{tabular}{|l|c|c|c|c|}
\hline \multirow{2}{*}{$\begin{array}{c}\text { Causality Assessment } \\
\text { based on naranjos scale }\end{array}$} & \multicolumn{4}{|c|}{ Poly pharmacy } \\
\cline { 2 - 5 } & Major & \% & Minor & \% \\
\hline Definite & 19 & 18.62 & 5 & 41.66 \\
Probable & 51 & 49.09 & 1 & 8.33 \\
Possible & 32 & 31.37 & 6 & 50 \\
Unlikely & 00 & 00 & 00 & 00 \\
\hline Total & $\mathbf{1 0 2}$ & $\mathbf{1 0 0}$ & $\mathbf{1 2}$ & $\mathbf{1 0 0}$ \\
\hline
\end{tabular}

Around 15 ADRs were found in respiratory diseases like copd, pneumonia, emphysema and asthma. 11 in renal disease patients, 45 in cardiovascular disease patients, 17 in infectious disease patients, 8 in endocrine disease patients , 10 in hematological disease patients and 8 in hepatic disease patients. Suspected ADRs were presented in table: 6 based on therapeutic category.

Table: 6 Suspected ADRs and causality assessment

\begin{tabular}{|c|c|c|c|}
\hline Suspected drug & Suspected reaction & Number of ADRs & Naranjos scale \\
\hline $\begin{array}{l}\text { NSAIDs } \\
\text { Diclofenac } \\
\text { Aspirin } \\
\text { Ibuprofen }\end{array}$ & $\begin{array}{c}\text { Gastritis } \\
\text { GI-bleeding } \\
\text { Angioneuritic edema }\end{array}$ & $\begin{array}{l}5 \\
1 \\
1\end{array}$ & $\begin{array}{l}\text { Probable } \\
\text { Probable } \\
\text { Probable }\end{array}$ \\
\hline $\begin{array}{l}\text { Anti-cholinergic drugs } \\
\text { Atropine } \\
\text { Benzhexol } \\
\text { Cyclopam }\end{array}$ & $\begin{array}{l}\text { Dryness of mouth } \\
\text { Dryness of mouth } \\
\text { Stomach discomfort }\end{array}$ & $\begin{array}{l}5 \\
3 \\
1 \\
\end{array}$ & $\begin{array}{l}\text { Definite } \\
\text { Possible } \\
\text { Possible }\end{array}$ \\
\hline $\begin{array}{l}\text { Sympathomimmetic amine } \\
\text { Dopamine } \\
\text { Dobutamine } \\
\text { Adrenalin }\end{array}$ & $\begin{array}{c}\text { Tachycardia } \\
\text { Tachycardia } \\
\text { Tremors } \\
\end{array}$ & $\begin{array}{l}3 \\
2 \\
1\end{array}$ & $\begin{array}{l}\text { Probable } \\
\text { Possible } \\
\text { Probable }\end{array}$ \\
\hline $\begin{array}{l}\text { Diuretics } \\
\text { Frusemide } \\
\text { Spiranolactone } \\
\end{array}$ & $\begin{array}{l}\text { Hypokalemia } \\
\text { Hyperkalemia }\end{array}$ & $\begin{array}{l}6 \\
4 \\
\end{array}$ & $\begin{array}{l}\text { Definite } \\
\text { Definite }\end{array}$ \\
\hline $\begin{array}{l}\text { Anti-histamines } \\
\text { Cetrizine } \\
\text { Avil }\end{array}$ & $\begin{array}{l}\text { Drowsiness } \\
\text { Drowsiness }\end{array}$ & $\begin{array}{l}7 \\
5\end{array}$ & $\begin{array}{l}\text { Probable } \\
\text { Possible }\end{array}$ \\
\hline $\begin{array}{l}\text { Corticosteroids } \\
\text { Prednisolone } \\
\text { Hydrocortisone } \\
\text { Dexamethasone }\end{array}$ & $\begin{array}{l}\text { Hyperglycemia } \\
\text { Cushing syndrome } \\
\text { Hypertension }\end{array}$ & $\begin{array}{l}2 \\
2 \\
1\end{array}$ & $\begin{array}{l}\text { Possible } \\
\text { Possible } \\
\text { Possible }\end{array}$ \\
\hline $\begin{array}{l}\text { Oral-hypoglysemic } \\
\text { Metformin } \\
\text { Glimipride }\end{array}$ & $\begin{array}{l}\text { Metallic taste } \\
\text { Hypoglycemia }\end{array}$ & $\begin{array}{l}3 \\
2\end{array}$ & $\begin{array}{l}\text { Probable } \\
\text { Probable }\end{array}$ \\
\hline $\begin{array}{l}\text { Anti- coagulants } \\
\text { Heparin }\end{array}$ & Urticaria & 2 & Definite \\
\hline $\begin{array}{l}\text { Anti- platelets } \\
\text { Ecospirin }\end{array}$ & Urticaria & 5 & Definite \\
\hline $\begin{array}{l}\text { Anti- epileptics } \\
\text { Phenytoin } \\
\text { Phenobarbitone } \\
\text { Valproic acid }\end{array}$ & $\begin{array}{c}\text { Gingival hyperplasia } \\
\text { Anemia } \\
\text { Hepatitis }\end{array}$ & $\begin{array}{l}2 \\
1 \\
1\end{array}$ & $\begin{array}{l}\text { Probable } \\
\text { Probable } \\
\text { Possible }\end{array}$ \\
\hline
\end{tabular}




\begin{tabular}{|l|c|c|c|}
\hline Opioids & Respiratory depression & 1 & Possible \\
\hline Tramadol & Weight gain & 1 & Possible \\
\hline $\begin{array}{l}\text { Antipsychotic } \\
\text { Olanzapine }\end{array}$ & Salivation & 3 & Probable \\
\hline Anti-manic & Tremors & 4 & Probable \\
Lithium & Hypotension & 1 & Probable \\
\hline Anti-hyprtensive drugs & Reflex tachycardia & 1 & Possible \\
Losartan & Pedal edema & 1 & Possible \\
Nefedipine & Dry cough & 5 & Probable \\
Amlodipine & Head ach & & \\
Enalapril & & 8 & Probable \\
\hline Anti-anginal drugs & Puscle weekness & 10 & Possible \\
Nitroglycerin & & & \\
\hline Hypolipedemic drugs & Anemia & 1 & Definite \\
Atorvastatin & Allergic reactions & 2 & Possible \\
\hline Anti retroviral drugs & Skin rashes & 1 & Probable \\
Zidovudine & Epigastric pain & 2 & Probable \\
\hline Anti- biotics & Nephro-toxicity & 1 & Definite \\
Ceftriaxone & Diarrhea & 3 & Definite \\
Cefixime & Skin rashes & 2 & Definite \\
Azithromycin & Metallic taste & 2 & Possible \\
Amikacin & & & \\
Augmentin & & & \\
Fluconazole & Metronidazole & & \\
\hline
\end{tabular}

\section{DISCUSSION}

Polypharmacy was a frequent condition in Indian population and mainly depends on the type of the diseases, co-morbid conditions, hereditary, economic status and malnutrition. Our present study showed that adults and young elder patients were more prone to polypharmacy due to different types of diseases with other co-morbid conditions. Among 448 cases, males were 246 and females were 202. Out of 448 cases 252 patients were found to be with major polypharmacy and 196 were with minor polypharmacy. Out of 252 major polypharmacy patients, $34.12 \%$ of the patients were found in MICU followed by $55.55 \%$ in MMW, $14.28 \%$ in FMW, 10.31in PSY and 9.92\% in DVL. There are $51.75 \%$ ADRs were identified in males and $48.24 \%$ ADRs were identified in females. Among 114 ADRs, 22.80\% from MICU, $31.57 \%$ from MMW, 27.19\% from FMW, $10.52 \%$ from PSY and 7.89 from DVL, Most commonly prescribed drugs were enalapril, followed by ceftriaxone, hydrocortisone, phenytoin and metformin. Out of the 114 ADRs, 105 were accepted by physician and 9 were suspected. Among them34 ADRs were Type-A (augmented), 84 ADRs were Type-B (bizzare). Of these 14 ADRs were identified in patients had minor polypharmacy and 100 ADRs in patients had major polypharmacy. The causality assessment revealed that all suspected ADR'S fell under the definitely, probable and possible. The goal should be to prescribe the least complex drug regimen for the patient as possible while considering the medication problem and symptoms and of-course the cost of therapy.

\section{CONCLUSION}

Building awareness to healthcare professionals for spontaneous reporting of adverse drug reaction and following the evidence based medicine (EBM) would help in preventing polypharmacy and medication related problems like ADR. The 
role of pharmacists is important to continually educate but also to have access to complete patient records. So they could look at all of the medications that may be given to the patient for better patient care.

\section{AKNOWLEDGEMENT}

We are thankful to health care professionals of Rajiv Gandhi Institute of Medical Sciences (RIMS), Kadapa and our college professors (Department of Pharmacy Practice) for their encouragement and support to conduct the study.

\section{REFERENCES}

1. Linda R Tulner, Indeborg MJA Kuper, Suzanne V Rank fort, Jos PCM Van campen, cornelis HW KoKs, Desiderius PM Brandjer, Jos $\mathrm{H}$ Beijnen. Disscrepanciesin reported drug use in geriatric out patients: Relevance to advers events and drug drug intractions $\mathbf{J}$ AMJOpharm 2009:7(2):

2. Nimmy N John, RH Udupi, KM Binnu. Incidance of polypharmacy induced drug intractions in a tertiary care hospital. Intrnational Journal of Pharmaceuticals and Research 2012:3(7):2119-21

3. Parthasarathi G, Karin N, Hansen, Milap N. A text book of clinical pharmacy practice. P. 8-97

4. Akshaya Sreekanth, G Sireesha Assesment on the prevalence of polypharmacy in Urban population. Inventi Impact: Pharmacy Practice 2012:4:2229-4201

5. Shamna M, Dilip C, Ajmal M, Linu Mohan P, C CP Jafer, Yahiya Mohammed. A Prespective study on Adverse Drug Reaction of Anti Biotics in tertiory care hospital J. JSPS 2015:6 (4): 1-6

6. Subhatara Swamy. Bhanu Prakash, Prathiba Ndigi, Murali Mohan and Manjula Shetty. Profile of suspect ADR in a tertiory teaching care hospital $\mathbf{J}$ Pharmacol Clin Toxicol 1005:141:1-5

7. Lobo et al Adverse Drug Reaction Monitoring: support for Pharmacovigilance at a teaching care hospital in Northen Brazil, BMC Pharmacology and Toxicology 2013: 14: 5. http://dr. doi. Org /10. 1186/ 2050-6511-14-5. 